\title{
Microhabitats Utilization by Solitary Parasitoids and Predatory Insects as Indicators of Oil Palm Agroecosystem's Capacity to Support Insect Species Diversity
}

\author{
(Penggunaan Mikrohabitat oleh Parasitoid Tunggal dan Serangga Pemangsa sebagai Penunjuk Kapasiti
}

Agroekosistem Kelapa Sawit dalam Menyokong Kepelbagaian Spesies Serangga)

Ahmad Bukhary, A.K.*, Ruslan, M.Y., Noor Hisham, H., MuZamil, M., Abu Hassan, A. \& Idris, A.B.

\section{ABSTRACT}

Microhabitats capacity to support insect species diversity and persistence were evaluated implementing solitary parasitoids and predatory insects according to different phases of herbicide and chemical fertilizer applications. Two species of the genus Xanthopimpla (Ichneumonidae) and one species of the genus Pompilus (Pompilidae) showed relationships on vegetation-type microhabitats, notably natural weeds, leguminous cover crops, and the beneficial plant Turnera subulata, while two species of the genus Evania (Evaniidae) showed relationships with chipped oil palm trunks. One species from the genus Odontomachus (Formicidae) as an exclusive predatory ant was related to both chipped oil palm trunks and the beneficial plant $\mathrm{T}$. subulata. Xanthopimpla parasitoids exhibited abundance fluctuations difference around natural weeds during herbicide application phases between three- and six-years old oil palm stands, with decreased and increased abundance patterns of the former and the latter, respectively. 18 years old oil palm stand showed increased abundance patterns only along with the different phases of chemical fertilizer applications. The importance of natural weeds diversity, restrictions of leguminous cover crops, frequency of herbicide applications, and the arrangements between beneficial plants and wood-based microhabitats that benefited insect parasitoids and predators were discussed.

Keywords: Microhabitats; oil palm; parasitoid; predator; utilization

\section{ABSTRAK}

Kapasiti mikrohabitat untuk menyokong kepelbagaian dan pengekalan spesies serangga telah dinilai dengan menggunakan parasitoid tunggal dan serangga pemangsa berdasarkan kepada fasa penggunaan racun rumpai dan baja kimia yang berbeza. Dua spesies daripada genus Xanthopimpla (Ichneumonidae) dan satu spesies daripada genus Pompilus (Pompilidae) menunjukkan perhubungan terhadap mikrohabitat berasaskan vegetasi, melibatkan rumpai liar, tanaman legum penutup bumi, serta tumbuhan berguna Turnera subulata, manakala dua spesies daripada genus Evania (Evaniidae) menunjukkan perhubungan dengan batang kelapa sawit yang diracik. Satu spesies daripada genus Odontomachus (Formicidae) sebagai satu semut pemangsa khas berkait dengan batang kelapa sawit yang diracik dan tumbuhan berguna T. subulata. Parasitoid Xanthopimpla menunjukkan perbezaan terhadap perubahan kelimpahan pada rumpai liar semasa penggunaan racun rumpai antara ladang kelapa sawit berumur tiga dan enam tahun, masingmasing dengan corak penurunan dan peningkatan kelimpahan. Ladang kelapa sawit berumur 18 tahun menunjukkan peningkatan corak kelimpahan hanya pada fasa penggunaan baja kimia yang berbeza. Kepentingan kepelbagaian rumpai liar, kekangan tanaman legum penutup bumi, kekerapan penggunaan racun rumpai dan susunan antara tumbuhan berguna dan mikrohabitat berasaskan kayuan yang memberikan manfaat kepada serangga parasitoid dan pemangsa dibincangkan.

Kata kunci: Kelapa sawit; mikrohabitat; parasitoid; pemangsa; penggunaan

\section{INTRODUCTION}

Diversity statuses of organisms within oil palm agroecosystem have been in arguments since more than a decade ago (Edwards et al. 2010; Fitzherbert et al.
2008; Koh 2008; Koh \& Wilcove 2008, 2007), with more emphasized given to the groups of vertebrates than invertebrates (Aratrakorn et al. 2006; Maddox et al. 2007), although extensive biodiversity and ecological studies have been done on invertebrates, primarily to insect 
groups (Bong et al. 2012; Brühl \& Eltz 2010; Chung et al. 2000; Liow et al. 2001). Most studies done were related to different taxa and of different oil palm plots, focusing on any existing forest-related microhabitats within oil palm plantations that could support diversity and species persistence (Fayle et al. 2010; Turner \& Foster 2009).

Since the formation of the Roundtable on Sustainable Palm Oil (RSPO) in 2004 for the purpose of monitoring management processes related to producing a more sustainable palm oil globally, there are eight main principles and related criteria updated annually, and the fifth principle is related to the environmental responsibility and conservation of natural resources and biodiversity (RSPO 2013). Furthermore, in recent years, Malaysia has formed the Malaysian Sustainable Palm Oil (MSPO), supporting the smallholders to have official certifications in the production and exportation of palm oils ( $\mathrm{Ng} 2016$ ), and similar to RSPO, has one of the principles related to the maintenance of biodiversity.

However, the least comprehend aspect is the overlapping between oil palm plantations' management practices and impacts on biodiversity, as for both RSPO and MSPO, management practices for growers and the maintenance of biodiversity are listed separately, making direct comparisons between the two to be unclear and imprecise (Azhar et al. 2015, 2011). The findings from researchers concerned with forest-specific microhabitats, while for managers and growers more concerned about management practices, has formed a large gap in understanding the exact nature of management impacts on diversity, and microhabitat as an element that connected the two factors (Mehrabi et al. 2014).

The most quintessential step in understanding the influences of general oil palm plantations' management practices is to search for key indicator species (Lindenmayer et al. 2000). Some insect species are more sensitive to environmental changes than others, becoming important ecological indicators for many ecologists (Idris et al. 2003; Ng \& Idris 2015). Apart from focusing on any existing or remnants of forest-related microhabitats, or at least any importation of forest-related structures into oil palm agro-ecosystem landscapes (Chung et al. 2000), it is more crucial to delve in-depth pertained to oil palm specific microhabitats (Ahmad Bukhary et al. 2017a). Hence, this study is done to elucidate the impacts of oil palm management practices exclusively to parasitoid and predator insects inhabiting oil palm-specific microhabitats as key indicators, and related microhabitats' capacity to sustain diversity through species persistence.

\section{MATERIALS AND Methods}

Field samplings were done at Felda Sungai Tekam oil palm plantations, Jerantut, Pahang, from February 2013 to February 2014. Five oil palm age stand types were chosen, viz., less than a year old (N03'54'592" E102'31'502"), three years old (N03 ${ }^{\circ} 54^{\prime} 052^{\prime \prime}$ E $\left.102^{\circ} 32^{\prime} 062^{\prime \prime}\right)$, six years old (N03 ${ }^{\circ} 54^{\prime} 253^{\prime \prime}$ E10232'184"), 18 years old (N03'53'592" E102 31'482"), and 23 years old (N0355'024” E102 30'482”). Total area $\left(\mathrm{m}^{2}\right)$ covered by one oil palm age stand was $100 \mathrm{~m}$ length $\times 100 \mathrm{~m}$ width. Each age stand has four plot replicates of similar total area covered. Collection of insect parasitoids and predators involved the employment of the Malaise trap (MT), the passive pit-fall trap (PPT), and the newly modified pit-light trap (MPLT) (Ahmad Bukhary et al. 2017b) from earlier designs invented by Heap (1988) and redesigned by Hébert et al. (2000). Four MT and MPLT units, as well as 100 PPT units were employed per one plot replicate per oil palm age stand type. Samplings were done in two sessions per sampling month, with one sampling session equal to one week. Additional sampling sessions were done to any sampling months with heavy rainfalls, related to either severely damaged traps (MTs) or samples missing due to heavy flooding (PPTs and MPLTs).

Insect samples were brought to the entomological laboratory for sorting purposes. Predators from all known orders were sorted first, then followed by hymenopteran and dipteran parasitoids. Insect predators and dipteran parasitoids were identified based on Borror and White (1970), Hashimoto (2003), and Triplehorn and Johnson (2005). Hymenopteran parasitoids were identified based on Goulet and Hubert (1993). Several unidentified species were assigned as morpho-species following known subfamilies (Krell 2004). Five insect predators and parasitoids per species or morpho-species were pinned by implementing entomological pins and referred as the representative sample. Microhabitats were categorized as either vegetation-type (natural weeds, leguminous cover crops, beneficial plants) or wood-based (chipped oil palm trunks, empty fruit bunches, rotting fronds).

Natural weeds (NW) and leguminous cover crops (LCC) were quantitatively measured using a standard 1 $\mathrm{m} \times 1 \mathrm{~m}$ quadrate (Dodd 2011; Krebs 1999), 50 quadrate units per oil palm plot per age stand type, arranged in a systematic grid ( 5 quadrate units per row grids of $7 \mathrm{~m}$ apart, and 10 quadrate units per column grids; $9 \mathrm{~m}$ apart) with total area covered of $49 \mathrm{~m}$ length $\times 108 \mathrm{~m}$ width. Standard measuring tape was used to measure the area covered by both NW and LCC for each quadrate unit. Beneficial 
plants were measured in two ways; a. based on standard volume formula $\left(\mathrm{m}^{3}\right)$ and $\mathrm{b}$. floral structures density per length covered (Eberhardt 1978). Piles of chipped oil palm trunks, empty fruit bunches, and rotting fronds followed the standard volume formula $\left(\mathrm{m}^{3}\right)$.

Relationships of parasitoid and predator communities with respective microhabitats were assessed implementing parametric Canonical Correspondence Analysis (CCA) using PC-ORD software version 6.0 (McCune \& Mefford 2011), with prior monotonic fourth-root $(0.25 \sqrt{ })$ transformation of main matrix species abundance data using IBM SPSS software version 24.0 (IBM Corp. 2016). Appropriate ordination axes were selected based on percentage of variance in distance matrix. Correlations with the main and second matrices were paralleled to observe relationships between species and variables of similar axes (McCune \& Mefford 2011; Peck 2010). Abundance differences of selected insect parasitoid and predator species per different management activity phases were evaluated based on One-Way ANOVA with Tukey's pos $h o c$ tests separately for herbicides and chemical fertilizers with abundance transformed following the formula $\log _{10}$ $(\mathrm{x}+1)$ using Minitab software version 17.1.0 (Minitab 2013).

\section{RESULTS}

A total of 11 families, 20 subfamilies, and 41 species recorded for insect parasitoid, and 12 families, 22 subfamilies, and 40 species recorded for insect predators. Relationships among solitary parasitoids with vegetation-type microhabitats according to CCA for Axis 1 showed that Xanthopimpla-sp1 (Figure 1), Xanthopimplasp2 (Figure 2), and Pompilus-sp1 (Figure 3) were related to natural weeds, leguminous cover crops, and the beneficial plant T. subulata, while for Axis 2, Pompilus-sp2 was correlated to the beneficial plant A. leptopus (Table 1).

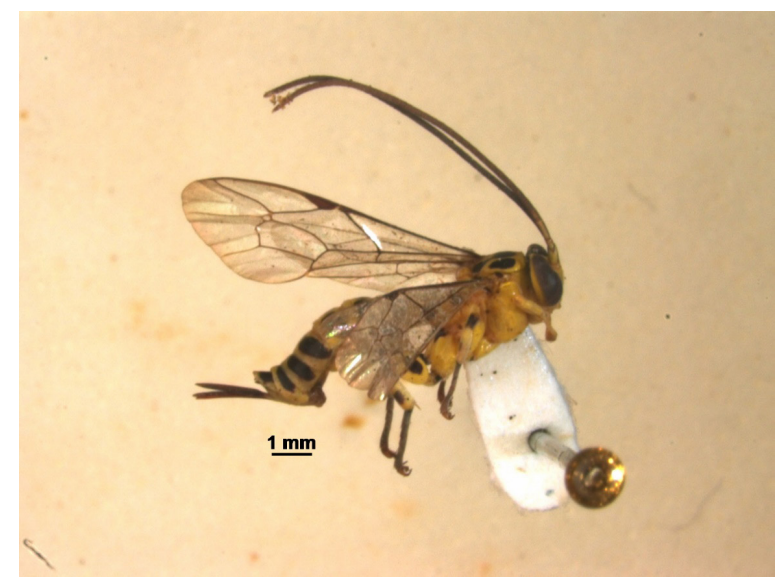

FIGURE 1. Xanthopimpla-sp1 (Ichneumonidae: Pimplinae)

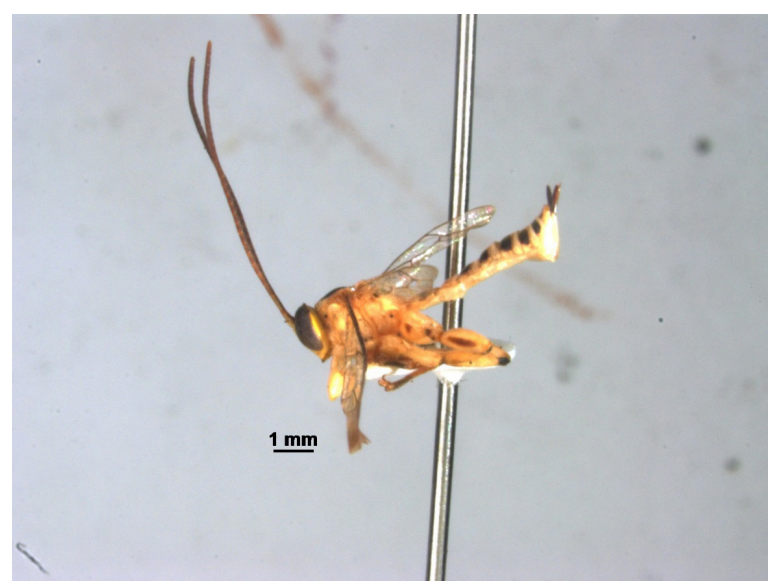

FIGURE 2. Xanthopimpla-sp2 (Ichneumonidae: Pimplinae) 


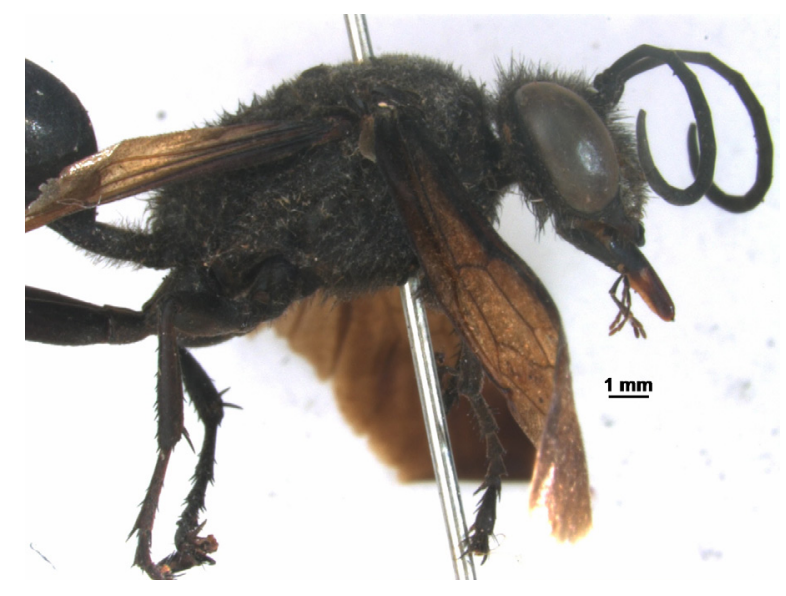

FIGURE 3. Pompilus-sp1 (Pompilidae: Pompilinae)

TABLE 1. Canonical Correspondence Analysis (CCA) for insect parasitoid community to vegetation-type microhabitats within different oil palm age stands

\begin{tabular}{|c|c|c|c|c|c|c|}
\hline \multirow[b]{2}{*}{ Species } & \multicolumn{3}{|c|}{ Axis 1} & \multicolumn{3}{|c|}{ Axis 2} \\
\hline & $\mathrm{r}$ & $r^{2}$ & $\tau$ & $\mathrm{r}$ & $r^{2}$ & $\tau$ \\
\hline Xanthopimpla-sp1 & 0.775 & 0.723 & 0.544 & 0.308 & 0.095 & -0.166 \\
\hline Xanthopimpla-sp2 & 0.751 & 0.873 & 0.641 & 0.462 & 0.214 & -0.230 \\
\hline Pompilus-sp1 & 0.781 & 0.739 & 0.617 & 0.079 & 0.006 & 0.102 \\
\hline Pompilus-sp2 & 0.047 & 0.002 & -0.088 & -0.725 & 0.888 & -0.573 \\
\hline \multicolumn{7}{|l|}{ Microhabitat(s) } \\
\hline NW* & -0.739 & 0.709 & -0.533 & -0.366 & 0.134 & -0.047 \\
\hline LCC & 0.783 & 0.713 & 0.583 & -0.458 & 0.210 & -0.120 \\
\hline ANTlep & 0.157 & 0.025 & 0.285 & -0.839 & 0.704 & -0.712 \\
\hline TURsub末 & 0.817 & 0.768 & 0.597 & 0.458 & 0.210 & 0.489 \\
\hline
\end{tabular}

Note: Bold letters and numbers showed highly correlated species to respective microhabitat(s)

$\$ N W$ : natural weeds; LCC: leguminous cover crops; ANTlep: Antigonon leptopus. TURsub: Turnera subulata 
For predatory insects, Odontomachus-sp1 (Figure 4) was the only one predatory ant species, related to natural weeds and the beneficial plant T. subulata as of CCA in Axis 2 (Table 2).

TABLE 2. Canonical Correspondence Analysis (CCA) for insect predator community to vegetation-type microhabitats within different oil palm age stands

\begin{tabular}{|c|c|c|c|c|c|c|}
\hline \multirow[b]{2}{*}{ Species } & \multicolumn{3}{|c|}{ Axis 2} & \multicolumn{3}{|c|}{ Axis 3} \\
\hline & $\mathrm{r}$ & $r^{2}$ & $\tau$ & $\mathrm{r}$ & $r^{2}$ & $\tau$ \\
\hline Odontomachus-sp1 & 0.888 & 0.746 & 0.657 & -0.097 & 0.009 & -0.014 \\
\hline \multicolumn{7}{|l|}{ Microhabitat(s) } \\
\hline NW: & -0.736 & 0.742 & -0.583 & 0.155 & 0.024 & 0.259 \\
\hline LCC & 0.232 & 0.054 & 0.005 & -0.754 & 0.868 & -0.748 \\
\hline ANTlep $\ddagger$ & -0.283 & 0.080 & -0.227 & 0.339 & 0.115 & 0.035 \\
\hline TURsubt & 0.865 & 0.748 & 0.562 & -0.504 & 0.254 & -0.398 \\
\hline
\end{tabular}

Note: Bold letters and numbers showed highly correlated species to respective microhabitat(s)

\$NW: natural weeds; LCC: leguminous cover crops; ANTlep: Antigonon leptopus. TURsub: Turnera subulata

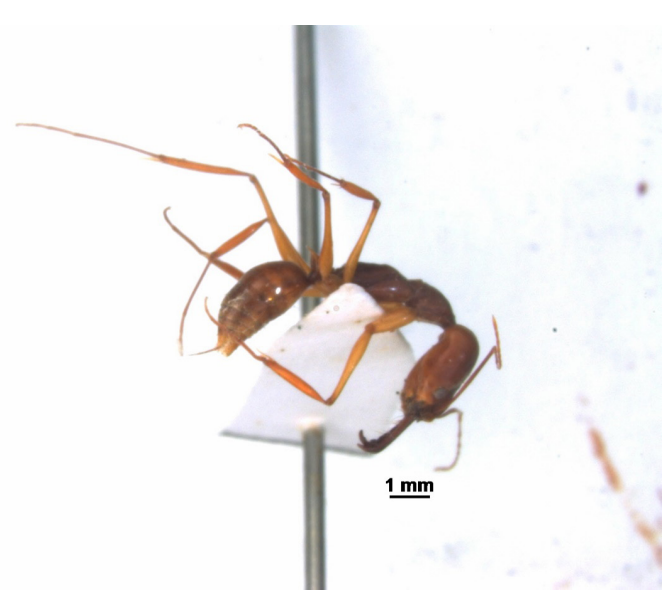

FIGURE 4. Odontomachus-sp1 (Formicidae: Ponerinae) 
For wood-based microhabitats and relationships among solitary parasitoids, Casinaria-sp1, Evania-sp1 (Figure 5) and Evania-sp2 (Figure 6) were related to oil palm chipped trunks as in Axis 2, and Xanthopimpla-sp3 was related to empty fruit bunch piles as of CCA in Axis 3 (Table 3).

TABLE 3. Canonical Correspondence Analysis (CCA) for insect parasitoid community to wood-based microhabitats within different oil palm age stands

\begin{tabular}{|c|c|c|c|c|c|c|}
\hline \multirow[b]{2}{*}{ Species } & \multicolumn{3}{|c|}{ Axis 2} & \multicolumn{3}{|c|}{ Axis 3} \\
\hline & $\mathrm{r}$ & $r^{2}$ & $\tau$ & $\mathrm{r}$ & $r^{2}$ & $\tau$ \\
\hline Xanthopimpla-sp3 & -0.063 & 0.004 & -0.081 & 0.723 & 0.836 & 0.624 \\
\hline Casinaria-sp1 & 0.817 & 0.867 & 0.525 & -0.118 & 0.014 & 0.085 \\
\hline Evania-sp1 & 0.739 & 0.722 & 0.543 & -0.144 & 0.021 & -0.115 \\
\hline Evania-sp2 & 0.808 & 0.771 & 0.664 & -0.096 & 0.009 & -0.013 \\
\hline \multicolumn{7}{|l|}{ Microhabitat(s) } \\
\hline OPCT & 0.704 & 0.896 & 0.585 & -0.168 & 0.028 & 0.339 \\
\hline EFBP & -0.042 & 0.002 & -0.067 & 0.999 & 0.997 & 0.614 \\
\hline RFP! & 0.273 & 0.074 & 0.365 & -0.015 & 0.000 & -0.510 \\
\hline
\end{tabular}

Note: Bold letters and numbers showed highly correlated species to respective microhabitat(s)

†OPCT: oil palm chipped trunks. EFBP: empty fruit bunch piles. RPF: rotting frond piles

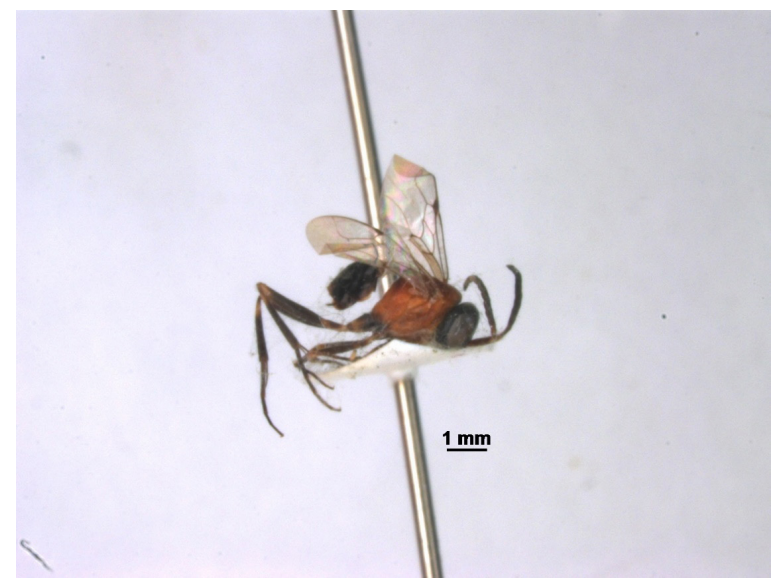

FIGURE 5. Evania-sp1 (Evaniidae: Evaniinae) 


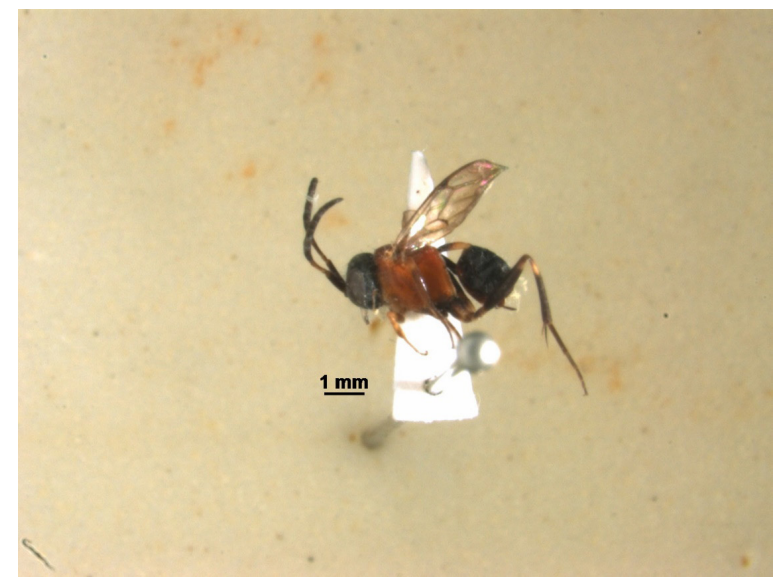

FIGURE 6. Evania-sp2 (Evaniidae: Evaniinae)

For predatory insects, Odontomachus-sp1 and Paederus-sp1 both were related to oil palm chipped trunks as of CCA in Axis 2 (Table 4).

TABLE 4. Canonical Correspondence Analysis (CCA) for insect predator community to wood-based microhabitats within different oil palm age stands

\begin{tabular}{|c|c|c|c|c|c|c|}
\hline \multirow[b]{2}{*}{ Species } & \multicolumn{3}{|c|}{ Axis 2} & \multicolumn{3}{|c|}{ Axis 3} \\
\hline & $\mathrm{r}$ & $\mathrm{r}^{2}$ & $\tau$ & $\mathrm{r}$ & $\mathrm{r}^{2}$ & $\tau$ \\
\hline Paederus-sp1 & 0.728 & 0.894 & 0.598 & 0.033 & 0.001 & 0.076 \\
\hline Odontomachus-sp1 & 0.776 & 0.702 & 0.578 & -0.074 & 0.005 & -0.025 \\
\hline \multicolumn{7}{|l|}{ Microhabitat(s) } \\
\hline OPCT & 0.989 & 0.977 & 0.614 & -0.049 & 0.002 & 0.044 \\
\hline EFBP & -0.155 & 0.024 & 0.093 & 0.925 & 0.855 & 0.602 \\
\hline RFP & -0.351 & 0.123 & 0.176 & 0.242 & 0.059 & 0.395 \\
\hline
\end{tabular}

Note: Bold letters and numbers showed highly correlated species to respective microhabitat(s) †OPCT: oil palm chipped trunks. EFBP: empty fruit bunch piles. RPF: rotting frond piles

One-way ANOVA showed that only three solitary parasitoid species, viz., Xanthopimpla-sp1 (NW; three years old; $\mathrm{F}=7.32$, d.f. $=2, \mathrm{p}=0.013$; six years old; $\mathrm{F}=$ 4.70 , d.f. $=2, p=0.040 ;$ LCC; less than one year old; $F=$
5.67, d.f. $=2, \mathrm{p}=0.026 ;$ TURsub; less than one year old; F $=5.67$, d.f. $=2, \mathrm{p}=0.026)$, Xanthopimpla-sp2 (LCC; less than one year old; $\mathrm{F}=8.04$, d.f. $=2, \mathrm{p}=0.010 ;$ TURsub; less than one year old; $F=8.04$, d.f. $=2, p=0.010$ ) and 
Pompilus-sp1 (NW; three years old; $\mathrm{F}=8.10$, d.f. $=2, \mathrm{p}=$ 0.010; LCC; less than one year old; $F=6.31$, d.f. $=2, p=$ 0.019 ; TURsub; less than one year old; $\mathrm{F}=6.31$, d.f. $=2, \mathrm{p}$ $=0.019)$, significantly have fluctuating abundance related to vegetation-type microhabitats as mentioned, according to different herbicide application phases (Table 5).

Evania-sp1 (OPCT; less than one-year-old; F = 11.98 , d.f. $=2, \mathrm{p}=0.003$ ) and Evania-sp2 (OPCT; less than one year old; $F=5.53$, d.f. $=2, p=0.027$ ) showed fluctuated abundances specifically related to oil palm chipped trunks (Table 5).
Odontomachus-sp1 was the only predatory ant species showing abundance fluctuations related to $T$. subulata (TURsub; less than one year old; $F=11.12$, d.f. $=2, \mathrm{p}=0.004)$ and oil palm chipped trunks (OPCT; less than one year old; $F=11.12$, d.f. $=2, p=0.004$ ) (Table 5). For different phases of chemical fertilizer applications, Xanthopimpla-sp1 showed fluctuated abundance related to natural weeds of 18 years old oil palm stand $(\mathrm{NW} ; 18$ years old; $\mathrm{F}=6.52$, d.f. $=2, \mathrm{p}=0.018$ ), while Pompilussp1 showed fluctuated abundance related to T. subulata (TURsub; less than one year old; $\mathrm{F}=4.79$, d.f. $=2, \mathrm{p}=$ 0.038) (Table 6).

TABLE 5. Abundance differences based on microhabitat utilizations by solitary wasp and predatory ant species according different phases of herbicide application

\begin{tabular}{|c|c|c|c|c|}
\hline \multirow[t]{3}{*}{ Microhabitat(s) } & \multirow{3}{*}{$\begin{array}{c}\text { Species } \\
\text { Parasitoid }\end{array}$} & \multicolumn{3}{|c|}{ Management type: Herbicide application } \\
\hline & & \multicolumn{3}{|c|}{ Management phases } \\
\hline & & pre- & during- & post- \\
\hline \multicolumn{5}{|l|}{ NW: } \\
\hline \multirow[t]{2}{*}{ Three years old } & Xanthopimpla-sp1 & $20.18 \pm 2.46 a$ & $6.49 \pm 3.74 b$ & $5.25 \pm 2.83 b$ \\
\hline & Pompilus-sp1 & $21.81 \pm 6.36 \mathrm{a}$ & $2.75 \pm 2.75 b$ & $1.18 \pm 0.91 b$ \\
\hline Six years old & Xanthopimpla-sp1 & $3.05 \pm 1.69 \mathrm{a}$ & $2.00 \pm 0.82 \mathrm{a}$ & $7.81 \pm 1.61 b$ \\
\hline \multicolumn{5}{|l|}{ LCC: } \\
\hline \multirow[t]{2}{*}{$<$ One year old } & Xanthopimpla-sp1 & $6.06 \pm 0.61 \mathrm{a}$ & $1.25 \pm 0.95 b$ & $5.42 \pm 1.53 \mathrm{a}$ \\
\hline & Pompilus-sp1 & $45.96 \pm 4.47 \mathrm{a}$ & $5.50 \pm 5.17 b$ & $24.30 \pm 12.20 \mathrm{a}$ \\
\hline Three years old & Xanthopimpla-sp2 & $28.07 \pm 2.05 \mathrm{a}$ & $3.64 \pm 2.11 b$ & $29.17 \pm 7.16 \mathrm{a}$ \\
\hline \multicolumn{5}{|l|}{ TURsubt } \\
\hline \multirow[t]{3}{*}{$<$ One year old } & Xanthopimpla-sp1 & $6.06 \pm 0.61 \mathrm{a}$ & $1.25 \pm 0.95 b$ & $5.42 \pm 1.53 \mathrm{a}$ \\
\hline & Xanthopimpla-sp2 & $32.07 \pm 3.07 \mathrm{a}$ & $4.75 \pm 2.95 b$ & $32.12 \pm 8.65 \mathrm{a}$ \\
\hline & Pompilus-sp1 & $45.96 \pm 4.47 \mathrm{a}$ & $5.50 \pm 5.17 \mathrm{~b}$ & $24.30 \pm 12.20 \mathrm{a}$ \\
\hline \multicolumn{5}{|l|}{ OPCT: } \\
\hline \multirow[t]{2}{*}{$<$ One year old } & Evania-sp1 & $14.25 \pm 1.25 \mathrm{a}$ & $12.24 \pm 3.39 b$ & $0.75 \pm 0.48 \mathrm{a}$ \\
\hline & Evania-sp2 & $26.37 \pm 2.82 \mathrm{a}$ & $4.00 \pm 3.67 b$ & $14.76 \pm 6.81 \mathrm{a}$ \\
\hline
\end{tabular}

Note: Mean \pm S.E. abundance values with different letters were significantly different from each other, based on One-Way ANOVA and Tukey's pos hoc tests at 95\% confidence level

$\$ N W$ : natural weeds; LCC: leguminous cover crops; TURsub: Turnera subulata; OPCT: oil palm chipped trunks 
TABLE 6. Abundance differences based on microhabitat utilizations by solitary wasp species according different phases of chemical fertilizer application

\begin{tabular}{|c|c|c|c|c|}
\hline \multirow[t]{3}{*}{ Microhabitat(s) } & \multirow[t]{2}{*}{ Species } & \multicolumn{3}{|c|}{ Management type: Chemical fertilizer application } \\
\hline & & \multicolumn{3}{|c|}{ Management phases } \\
\hline & Parasitoid & pre- & during- & post- \\
\hline \multicolumn{5}{|l|}{ NW } \\
\hline 18 years old & Xanthopimpla-sp1 & $1.81 \pm 0.28 \mathrm{a}$ & $1.75 \pm 0.89 \mathrm{a}$ & $3.29 \pm 0.61 b$ \\
\hline \multicolumn{5}{|l|}{ TURsubt } \\
\hline$<$ One year old & Pompilus-sp1 & $45.96 \pm 4.47 \mathrm{a}$ & $5.50 \pm 5.17 b$ & $24.30 \pm 12.20 \mathrm{a}$ \\
\hline
\end{tabular}

\section{DISCUSSION}

Five out of 41 parasitoid $(12.20 \%)$ insect species and one out of 40 predatory $(2.50 \%)$ insect species showed definite utilization on oil palm agroecosystem-specific microhabitats, verifying the notion that most insect species found within oil palm plantations were migrated temporarily from any nearest primary or secondary forest ecosystems (Lucey \& Hill 2012; Lucey et al. 2014), of the fact that most resources for eusocial wasps in the form of flowering plants that produced nectar and pollen sources (Marino \& Landis 1996) were much limited within oil palm plantations compared to forest ecosystems (Beggs 2001; Frost et al. 2015). This study emphasized two characteristics of insects' behavioural ecological aspects, primarily described as the ability to adapt to oil palm agroecosystem-specific microhabitats, and secondly the capacity to adapt to introduced environmental disturbances of oil palm-specific management activities of such microhabitats, reflected by most Xanthopimpla wasp species (Idris et al. 2003, 2001). The former notion however, is resource-dependent, and marked some characteristics of particular insect species that have the higher capacity to rapidly utilize any available resources and able to compete successfully with other less abundant species, increasing the pressure of inter-specific competitions, hence reducing overall species diversity (Fayle et al. 2010; Turner \& Foster 2009; Wang \& Foster 2016), reflected by Odontomachus ant species (Fowler 1980; Oliveira et al. 2011).
Solitary wasps other than Xanthopimpla sp., viz. Pompilus sp. and Evania sp. are more host-oriented (Klassen \& Sharanowski 2014; Punzo 2005), with several physiological restrictions (Tee \& Lee 2015), where the disturbance on vegetation structures around the epigeal level of oil palm plantations and the available piled wood-based microhabitats promoted the fluctuations in the abundances of host spiders (Bell et al. 2001; Churchill 1997) and wood cockroaches (Horn \& Hanula 2002), respectively. Ensign wasps of the family Evaniidae, although not a specific parasitoid of any known oil palm herbivorous pests, were found to be highly abundant within oil palm plantations as egg parasitoids of wood cockroaches (Bandung et al. 2019). Both Odontomachus sp. and Xanthopimpla spp. served as non-host-oriented environmental indicators, which is an essential characteristic as ecological indicators (Lindenmayer et al. 2000).

According to Norman and Othman (2016), Xanthopimpla spp. parasitoids can only be found around the oil palm plantations but not specifically found on beneficial flowering plants, where most chalcids (Brachymeria lasus, B. carinata, and B. lugubrious), along with braconids (Apanteles aluella and Dolichogenidea metesae), parasitoids of the bagworm pest, dominating the beneficial plants, hence further proving that Xanthopimpla spp. wasps were not host-oriented in utilizing the oil palm microhabitats, as well as depicting avoidance behaviour from other more highly abundant and social wasps. It is 
important to note that during the duration of this study, all the selected oil palm plantations were not infested by the bagworm pest, hence explaining why Xanthopimpla spp. wasps were significantly related to the available microhabitats. This study also not recording any individuals of the subfamily Microgastrinae, justifying the absence of the desired host species, and hence reducing the probability that bagworm specific parasitoids to utilize any available microhabitats. However, one species of the subfamily Chalcidinae, although not related to any of the oil palm-specific microhabitats based on the statistical analyses, was present with moderate in abundance, suggesting that this either could be any of the species of the genus Brachymeria (Norman \& Othman 2016).

Other studies also showed that Xanthopimpla spp. could be possible minor parasitoid regulating the bagworm pest populations, along with other major parasitoids such as Brachymeria sp., Apanteles sp., and Pediobius sp. (Kalidas 2012; Sankaran \& Syed 1972), suggesting that no record on the infestation of bagworm pest during the duration of this study could explain the significant relationships between Xanthopimpla spp. with other available microhabitats. It is important to note that this study was not design to assess the microhabitats' utilizations of any specific parasitoids or predators of particular oil palm insect pests, rather to evaluate the microhabitat utilizations of predators and parasitoids neutrally and naturally without the presence of specific desired pest species that could produce the 'pulling' effect on the parasitoids and predators. The findings of this study suggested that Xanthopimpla spp., with the dual nature of becoming the solitary parasitoid of bagworm pest, and avoiding other more abundant bagworm parasitoids, could be one of the essential species that indicate the presence-absence of bagworm infestations, along with the novel additional attribute as an indicator for the readiness of oil-palm specific microhabitats, such as beneficial flowering plants, to be utilized by other insects not specific as predators and parasitoids of bagworm pest. There is a possibility that most of major bagworm's parasitoids to be dispersed to nearest secondary forest habitats with higher nectar productivity, and presence of any lepidopteran larval forest defoliators, driving the dispersal activities (Frost et al. 2015), providing Xanthopimpla spp. wasps available opportunity to utilize available oil palm-specific microhabitats.

The microhabitat types and their arrangements currently existing within oil palm plantations are primarily focused on oil palm plantations' management feasibility and productivity (Samedani et al. 2015, 2014), such as providing natural organic fertilizers (Abu Hassan 2006) and increasing efficacy of biological control agents (Basri et al. 1999). Unfortunately these management-oriented microhabitats do not necessarily to be pragmatically habitable to most other wasps species unless under circumstances of the presence of certain specific host pest species (Heimpel \& Jervis 2004; Lewis et al. 1998), or preferred nectar-producing vegetation structures (Idris \& Grafius 1995; Idris \& Zaneedarwaty 2000), different from Xanthopimpla spp. wasp with the characteristics to adapt to environmental disturbances. This study proved that the presence-absence patterns of other wasps' species within oil palm agroecosystem to be of ephemeral in nature, and no clear stable wasps' community can be observed to be significantly adapting and utilizing the existing microhabitats. In fact, the beneficial plants $A$. leptopus has not exhibit any abundance fluctuations according to different phases of herbicide and chemical fertilizer applications, yet on the other hand T. subulata has been observed from this study as to be dominated by Odontomachus sp., recording the highest abundance during herbicide spraying processes, departed from empirical expectations of any active flying wasps' species to be the more desired indicators.

Xanthopimpla sp. as solitary wasp is an essential environmental indicator to quantify the capacity of oil palm agroecosystem in supporting insect species diversity and persistence, marked by the differential fluctuations of Xanthopimpla sp. abundances according to different oil palm age stands paralleled to different microhabitat structures and management activities, as of previous studies showed the capacity of Xanthopimpla sp. as primary indicators for disturbed forest ecosystems (Idris \& Kee 2002; Ng \& Idris 2015). Another essential characteristic of Xanthopimpla sp. evident from this study is that this wasp species has the ability to be an indicator for different management activities related to different oil palm age stand types, notably the 18 years old oil palm age stands, with increased abundance after chemical fertilizer applications, while for three and six years old oil palm stands are more specific to the herbicides applications, with opposing directions of Xanthopimpla sp. abundance fluctuations.

Furthermore, one fascinating finding of this study is that dominant predatory ant Odontomachus sp., utilized both closely arranged vegetation-type and wood-based microhabitats, compared to previous researches that showed the primary importance of most wood-based 
microhabitats (Ahmad Bukhary et al. 2017a) or vegetationtype microhabitats as the drivers for inter-specific competitions among ant species in disturbed areas (Fayle et al. 2010). Suitability of beneficial plant species as an element of vegetation-type microhabitats is essential in alleviating the rapid colonisations of highly dominant ant predators, promoting the persistence of other less dominant species (Ahmad Bukhary et al. 2017a; Mehrabi et al. 2014). Odontomachus sp. has been recorded to be existed in oil palm plantations (Nor Rasidah et al. 2010), and to be one of the ant species known to be highly abundant within oil palm plantations, and the sole species existed in most oil palm plantations is Odontomachus simillimus (Darmi et al. 2015; Nor Rasidah et al. 2010).

This study emphasized the importance between two inter-related factors that determined the stability of natural weeds community, the coverage of the canopy level, related to light penetration to the plantations' floors and overlapping of frond complexes, and spatial restrictions, related to the interactions of natural weed species with the planted leguminous cover crops. The oil palm of the age six years old has no spatial restrictions, referring to the absence of overlapping leguminous cover crops and expected to have higher weed species diversity, hence attracting more wasp species. However, since Xanthopimpla sp. showed higher abundance after the application of herbicides, it can be noted that the oil palm of the age six years old has lower natural weeds diversity compared to three years old oil palm stand, even with the presence of spatial restrictions by the leguminous cover crops (Mohamad et al. 2010). It can be hypothesized that, with the adequate amount of sunlight penetrating the plantations' floors, even with spatial restrictions, could promote natural weed species to diversify further compared to the plantations with fully covered canopy layers, with less capacity to diversify even without spatial restrictions (Essandoh et al. 2011). From the two factors mentioned, light penetration to the plantations' floors is superior to any spatial restrictions for promoting weed species diversity. Highly diverse weed species community alleviating inter-specific competitions, hence enabling any solitary wasps that are not adapted to the presence of other more abundant wasp species, including eusocial wasps, to persist and utilizing nectar resources without confined interactions.

The oil palm of the age 18 years old, although with overlapped frond complexes, but higher trunks' height, enabling sunlight to penetrate the plantations' floors diagonally, producing higher capacity for weed species diversification, marked by increased Xanthopimpla sp. abundance, and by the application of chemical fertilizers that might have accidental leaching process to the other parts of the plantations' floors, giving higher capacity and additional nutrients for the natural weeds' population growth. Marino and Landis (1996) had stressed about the importance of maintain vegetation complexes and diversity levels for the sustenance of wasps' species, reducing inter-specific competitions and promoting species cooccurrence, referring to the combination of all vegetationtype microhabitats in supporting insect species. This notion included that the presence of natural weeds as an important element for the long-term sustainable management of insect species diversity within oil palm plantations, and at the same time marking for actual insect species adapted to oil palm-specific microhabitats.

The combination of the right beneficial plant species, natural weeds, and leguminous cover crops collectively are all contributed to structural vegetation diversity, enhancing the probability to increase insect species diversity. The importance of each microhabitat with respective threshold and capacity measured as total surface area per volume to support differential species presence and persistence (Ranius \& Fahrig 2006). It is suggested from this study that, oil palm managers and workers should set new rules and regulations in managing existing natural weeds, where focusing on centralized or topical spraying patterns with least drifting effects as to conserve more flowering weeds on area-wide spatial scales. Similarly, spraying of herbicides must not depend on the thickness or volume of the natural weeds, but must paired with qualitative assessments and observations for the existing natural flowering weed species before spraying processes can be commenced as to achieve the balance between natural weeds management and conservation. Attractive and supportive microhabitats are important for stable assemblages of species, hence increasing the stability of food webs and species persistence, naturally rectifying diversity statuses (McCann 2000).

\section{REFERENCES}

Abu Hassan, A. 2006. FELDA Final Report on the Control of Rhinoceros Beetles (Oryctes rhinoceros) (Scarabaeidae: Coleoptera) in a Zero Burning Replanted Oil Palm Area, Felda Plantation, Lepar Utara, Pahang D.M. 2003-2006. Yayasan FELDA.

Ahmad Bukhary, A.K., Mohd Fauzi, M.M., Ruslan, M.Y., Noor Hisham, H., Izfa Riza, H., Abu Hassan, A. \& Idris, A.B. 2017a. Spatio-temporal dominant omnivorous antsaproxylic beetle species interactions around epigeal-based 
microhabitats within different oil palm age stand types. Malayan Nature Journal 69(1): 19-30.

Ahmad Bukhary, A.K., Mohd Fauzi, M.M., Ruslan, M.Y., Noor Hisham, H., Mohd Yusri, M.N., Izfa Riza, H., Abu Hassan, A. \& Idris, A.B. 2017b. Canopy versus epigeal beetle species differential diversity and feeding ecological characteristics employing light-based trapping methods across different oil palm age stand types. Serangga 22(1): 33-64.

Aratrakorn, S., Thunhikorn, S. \& Donald, P. 2006. Changes in bird communities following conversion of lowland forest to oil palm and rubber plantations in southern Thailand. Bird Conservation International 16: 71-82.

Azhar, B., Norzanalia, S., Puan, C.L., Norizah, K., Najjib, A., Siti, N. \& Fischer, J. 2015. Promoting landscape heterogeneity to improve the biodiversity benefits of certified palm oil production: Evidence from Peninsular Malaysia. Global Ecology and Conservation 3: 553-561.

Azhar, B., Lindenmayer, D.B., Wood, J., Fischer, J., Manning, A., Mcelhinny, C.M. \& Zakaria, M. 2011. The conservation value of oil palm plantation estates, smallholdings and logged peat swamp forest for birds. Forest Ecology and Management 262: 2306-2315.

Bandung, S., Ali, N., Syafrida, M. \& Damayanti, B. 2019. Patten of hymenopteran parasitoid community in oil palm plantations: Effects of age gradient or sampling methods? Advances in biological science research. In International Conference and the $10^{\text {th }}$ Congress of the Entomological Society of Indonesia (ICCESI 2019) Bali, Indonesia. pp. $75-82$.

Basri, M.W., Simon, S., Ravigadevi, S. \& Othman, A. 1999. Beneficial plants for the natural enemies of the bagworm in oil palm plantations. In Proceedings of the 1999 PORIM International Palm Oil Congress - Emerging Technologies and Opportunities in the Next Millennium, Kuala Lumpur, Malaysia. pp. 441-455.

Beggs, J. 2001. The ecological consequences of social wasps (Vespula sp.) invading an ecosystem that has an abundant carbohydrate resource. Biological Conservation 99: 17-28.

Bell, J.R., Wheater, C.P. \& Cullen, W.R. 2001. The implications of grassland and heathland management for the conservation of spider communities: A review. Journal of Zoology 255: 377-387.

Bong, J.C.F., King, P.J.H., Ong, K.H. \& Mahadi, N.M. 2012. Termite assemblages in oil palm plantation in Sarawak, Malaysia. Journal of Entomology 9(2): 68-78.

Borror, D.J. \& White, R.E. 1970. Peterson Field Guide - Insects of North America. New York: Houghton Mifflin Company. p. 404.

Brühl, C.A. \& Eltz, T. 2010. Fuelling the biodiversity crisis: Species loss of ground-dwelling forest ants in oil palm plantations in Sabah, Malaysia (Borneo). Biodiversity and Conservation 19: 519-529.

Chung, A.Y.C., Eggleton, P., Speight, M.R., Hammond, P.M. \& Chey, V.K. 2000. The diversity of beetle assemblages in different habitat types in Sabah, Malaysia. Bulletin of
Entomological Research 90: 475-496.

Churchill, T.B. 1997. Spiders as ecological indicators: An overview for Australia. Memoirs of Museum Victoria 56: 331-337.

Darmi, Budianta, D., Sabarudin \& Ridho, M.R. 2015. Communities of ants (Hymenoptera: Formicidae) in peatland planted with oil palm stands of different age strata. Advances in Environmental Biology 9(3): 473-480.

Dodd, M. 2011. Where are my quadrats? Position accuracy in fieldwork. Methods in Ecology and Evolution 2: 576-584.

Eberhardt, L.L. 1978. Transect methods for population studies. The Journal of Wildlife Management 42: 1-31.

Edwards, D.P., Hodgson, J.A., Hamer, K.C., Mitchell, S.L., Ahmad, A.H., Cornell, S.J. \& Wilcove, D.S. 2010. Wildlifefriendly oil palm plantations fail to protect biodiversity effectively. Conservation Letters 3: 236-242.

Essandoh, P.K., Armah, F.A., Odoi, J.O., Yawson, D.O. \& Afrifa, E.K.A. 2011. Floristic composition and abundance of weeds in an oil palm plantation in Ghana. ARPN Journal of Agricultural and Biological Sciences 6(1): 20-31.

Fayle, T.M., Turner, E.C., Snaddon, J.L., Chey, V.K., Chung, A.Y.C., Eggleton, P. \& Foster, W.A. 2010. Oil palm expansion into rain forest greatly reduces ant biodiversity in canopy, epiphytes and leaf-litter. Basic and Applied Ecology 11: 337-345.

Fitzherbert, E.B., Struebig, M.J., Morel, A., Danielsen, F., Brühl, C.A., Donald, P.F. \& Phalan, B. 2008. How will oil palm expansion affect biodiversity? Trends in Ecology \& Evolution 23(10): 538-545.

Fowler, H.G. 1980. Populations, prey capture and sharing, and foraging of the Paraguayan ponerine Odontomachus chelifer latreille. Journal of Natural History 14: 79-84.

Frost, C.M., Didham, R.K., Rand, T.A., Peralta, G. \& Tylianakis, J.M. 2015. Community-level net spillover of natural enemies from managed to natural forest. Ecology 96(1): 193-202.

Goulet, H. \& Hubert, J.F. 1993. Hymenoptera of the World: An Identification Guide to Families. Ottawa: Canada Communication Group-Publishing. p. 668.

Hashimoto, Y. 2003. Identification guide to the ant genera of Borneo. In Inventory and Collection Total Protocol for Understanding of Biodiversity, edited by Hashimoto, Y. \& Homathevi, R. Sabah: UMS Press. pp. 89-162.

Heap, M.A. 1988. The pit-light: A new trap for soil-dwelling insects. Australian Journal of Entomology 27: 239-240.

Heimpel, G.E. \& Jervis, M.A. 2004. Does floral nectar improve biological control by parasitoids? In Plant-provided Food and Plant-carnivore Mutualism, edited by Wäckers, F., van Rijn, P. \& Bruin, J. United Kingdom: Cambridge University Press.

Hébert, C., Jobin, L., Fréchette, M., Pelletier, G., Coulombe, C., Germain, C. \& Auger, M. 2000. An efficient pit-light trap to study beetle diversity. Journal of Insect Conservation 4(3): 189-200.

Horn, S. \& Hanula, J.L. 2002. Life history and habitat associations of the broad wood cockroach Parcoblatta lata (Blattaria: 
Blattellidae) and other native cockroaches in the Coastal Plain of South Carolina. Annals of the Entomological Society of America 95(6): 665-671.

IBM Corp. 2016. IBM SPSS Statistics for Windows, Version 24.0. New York: IBM Corp.

Idris, A.B. \& Kee, S.S. 2002. Horizontal and vertical diversity of Ichneumonid wasps (Hymenoptera: Ichneumonidae) in the Sungkai Wildlife Forest Reserve in Perak, Malaysia. Journal of Asia-Pacific Entomology 5: 85-89.

Idris, A.B. \& Nor Zaneedarwaty, N. 2000. The abundance and diversity of Braconidae in different habitats of Peninsular Malaysia. Journal of Biosciences 11(1 \& 2): 41-44.

Idris, A.B. \& Grafius, E. 1995. Wildflowers as nectar sources for Diadegma insulare (Hymenoptera: Ichneumonidae), a parasitoid of Diamondback Moth (Lepidoptera: Yponomeutidae). Environmental Entomology 24(6): 17261735.

Idris, A.B., Hanidah, J., Gonzaga, A.D. \& Nur Azura, A. 2003. Diversity, abundance, species composition and similarity of genus Xanthopimpla (Ichneumonidae: Pimplinae) in logged and fragmented forests of the Langat Basin in Selangor, Malaysia. Journal of Asia-Pacific Entomology 6(1): 1-8.

Idris, A.B., Gonzaga, A.D., Nor Zaneedarwaty, N., Hasnah, B.T. \& Natasha, B.Y. 2001. Does habitat disturbances have adverse effects on the diversity of parasitoid community? Journal of Biological Sciences 1(11): 1040-1042.

Kalidas, P. 2012. Pest problems of oil palm and management strategies for sustainability. Agrotechnology S11: 001.

Klassen, D.L. \& Sharanowski, B.J. 2014. First records of ensign wasps (Hymenoptera: Evaniidae) and their cockroach host (Blattodea: Blatellidae) in Manitoba. Proceedings of the Entomological Society of Manitoba 70: 11-14.

Krebs, C.J. 1999. Ecological Methodology. 2nd ed. California: Addison Wesley Longman Inc. p. 620.

Krell, F-T. 2004. Parataxonomy vs taxonomy in biodiversity studies - Pitfalls and applicability of 'morfo-species' sorting. Biodiversity and Conservation 13: 795-812.

Koh, L.P. 2008. Can oil palm plantations be made more hospitable for forest butterflies and birds? Journal of Applied Ecology 45: 1002-1009.

Koh, L.P. \& Wilcove, D.S. 2008. Is oil palm agriculture really destroying tropical biodiversity? Conservation Letters 1(2): 60-64.

Koh, L.P. \& Wilcove, D.S. 2007. Cashing in palm oil for conservation. Nature 448: 993-994.

Lewis, W.J., Stapel, J.O., Cortesero, A.M. \& Takasu, K. 1998. Understanding how parasitoids balance food and host needs: importance to biological control. Biological Control 11: 175-183.

Lindenmayer, D.B., Margules, C.R. \& Botkin, D.B. 2000. Indicators of biodiversity for ecologically sustainable forest management. Conservation Biology 14(4): 941-950.

Lucey, J.M. \& Hill, J.K. 2012. Spillover of insects from rain forest into adjacent oil palm plantations. Biotropica 44(3):
368-377.

Lucey, J.M., Tawatao, M., Senior, M.J.M., Khen, C.V., Benedick, S., Hamer, K.C., Woodcock, P., Newton, R.J., Bottrell, S.H. \& Hill, J.K. 2014. Tropical forest fragments contribute to species richness in adjacent oil palm plantations. Biological Conservation 169: 268-276.

Maddox, T., Priatna, D., Gemita, E. \& Salampessy, A. 2007. The conservation of tigers and other wildlife in oil palm plantations report no. 7. London, UK: Zoological Society of London.

Marino, P.C. \& Landis, D.A. 1996. Effect of landscape structure on parasitoid diversity and parasitism in agroecosystem. Ecological Applications 6(1): 276-284.

Mccann, K.S. 2000. The diversity-stability debate. Nature 405: 228-233.

Mccune, B. \& Mefford, M.J. 2011. PC-ORD - Multivariate Analysis of Ecological Data. version 6.0. Oregon: MjM Software.

Mehrabi, Z., Slade, E.M., Solis, A. \& Mann, D.J. 2014. The importance of microhabitat for biodiversity sampling. PLoS ONE 9(12): e114015.

MINITAB Inc. 2013. Minitab, Release 17.1.0. http://www. minitab.com. Accessed on 15 January 2013.

Mohamad, R.B., Wibawa, W., Mohd Ghazali, M., Puteh, A.B., Abdul Shukor, J., Yahya, A. \& Mohammad, M.L. 2010. Management of mixed weeds in young oil-palm plantation with selected broad-spectrum herbicides. Pertanika Journal of Tropical Agricultural Sciences 33(2): 193-203.

Ng, Y.F. \& Idris, A.B. 2015. Diversity, abundance and morphological variations of the Xanthopimpla (Ichneumonidae: Pimplinae) in different forest habitats. Sains Malaysiana 44(1): 1-6.

$\mathrm{Ng}, \mathrm{M}$. 2016. Malaysian sustainable palm oil (MSPO) to be made mandatory by 2019. Kuala Lumpur: Malaysian Palm Oil Council.

Norman, K. \& Othman, A. 2016. Diversity and activity of insect natural enemies of the bagworm (Lepidoptera: Psychidae) within an oil palm plantation in Perak, Malaysia. Journal of Oil Palm Research 28(3): 296-307.

Nor Rasidah, H., Wan Faridah Akmal, W.J. \& Mohd Nassrul Safre, M.N. 2010. Ant diversity in a Peninsular Malaysian mangrove forest and oil palm plantations. Asian Myrmecology 3: 5-8.

Oliveira, P.S., Camargo, R.X. \& Fourcassié, V. 2011. Nesting patterns, ecological correlates of polygyny and social organization in the Neotropical arboreal ant Odontomachus hastatus (Formicidae, Ponerinae). Insectes Sociaux 58: 207-217.

Peck, J.E. 2010. Multivariate Analysis for Communities Ecologists: Step by Step using PC-ORD. Oregon: MjM Software Design. p. 170.

Punzo, F. 2005. Experience affects hunting behavior of the wasp, Pepsis mildei Stål (Hymenoptera: Pompilidae). Journal 
of the New York Entomological Society 113(3\&4): 222229.

Ranius, T. \& Fahrig, L. 2006. Targets for maintenance of dead wood for biodiversity conservation based on extinction thresholds. Scandinavian Journal of Forest Research 21(3): 201-208

RSPO. 2013. Principles and Criteria for the Production of Sustainable Palm Oil Report. Geneva: RSPO.

Samedani, B., Juraimi, A.S., Rafii, M.Y., Sheikh Awadz, S.A., Anwar, M.P. \& Anuar, A.R. 2015. Effect of cover crops on weed suppression in oil palm plantation. International Journal of Agriculture and Biology 17: 251-260.

Samedani, B., Juraimi, A.S., Abdullah, S.A.S., Rafii, M.Y., Rahim, A.A. \& Anwar, M.P. 2014. Effect of cover crops on weed community and oil palm yield. International Journal of Agriculture and Biology 16: 23-31.

Sankaran, T. \& Syed, R.A. 1972. The natural enemies of bagworms on oil palms in Sabah, East Malaysia. Pacific Insects 14(1): 57-71.

Tee, H.S. \& Lee, C.Y. 2015. Water balance profiles, humidity preference and survival of two sympatric cockroach egg parasitoids Evania appendigaster and Aprostocetus hagenowii (Hymenoptera: Evaniidae; Eulophidae). Journal of Insect Physiology 77: 45-54.

Triplehorn, C.A. \& Johnson, N.F. 2005. Borror and DeLong's Introduction to the Study of Insects. 7th ed. USA: Thomson Brooks/Cole. p. 864.

Turner, E.C. \& Foster, W.A. 2009. The impact of forest conversion to oil palm on arthropod abundance and biomass in Sabah. Journal of Tropical Ecology 25: 23-30.

Wang, W.Y. \& Foster, W.A. 2016. Ground-foraging ant communities vary with oil palm age. Basic and Applied Ecology 17(1): 21-32.
Ahmad Bukhary, A.K.* \& Abu Hassan

School of Biological Sciences

Universiti Sains Malaysia

11800 USM Gelugor, Pulau Pinang

Malaysia

Ruslan, M.Y. \& Idris, A.B

Center for Insect Systematics

School of Environmental Sciences and Natural Resources Faculty of Science and Technology

Universiti Kebangsaan Malaysia

43600 UKM Bangi, Selangor Darul Ehsan

Malaysia

Noor Hisham, $\mathrm{H}$.

FGV Innovation Centre

PT23417, Lengkuk Teknologi

71760 Bandar Enstek, Negeri Sembilan Darul Khusus Malaysia

Muzamil, M.

Universiti Teknologi MARA, Cawangan Pahang

Bandar Tun Abdul Razak

26400 Jengka, Pahang Darul Makmur

Malaysia

*Corresponding author; email: abukhary@usm.my

Received: 23 June 2020

Accepted: 25 December 2020 